\title{
Institutional Framework on the Right to Information in Selected Jurisdictions
}

\author{
Ngozi J. Udombana1, Kafayat Motilewa Quadri² \\ ${ }^{1}$ Akinola Aguda School of Postgraduate Studies, Nigerian Institute of Advanced Legal Studies, University of Lagos Campus, \\ Akoka, Lagos, Nigeria \\ ${ }^{2}$ Department of Public Law, Nigerian Institute of Advanced Legal Studies, University of Lagos Campus, Akoka, Lagos, Nigeria \\ Email: ebubechi8@yahoo.com, keefayahg@gmail.com
}

How to cite this paper: Udombana, N. J., \& Quadri, K. M. (2020). Institutional Framework on the Right to Information in Selected Jurisdictions. Beijing Law Review, 11, 244-261. https://doi.org/10.4236/blr.2020.111017

Received: January 21, 2020

Accepted: March 15, 2020

Published: March 18, 2020

Copyright (c) 2020 by author(s) and Scientific Research Publishing Inc. This work is licensed under the Creative Commons Attribution International License (CC BY 4.0).

http://creativecommons.org/licenses/by/4.0/ (c) (i) Open Access

\begin{abstract}
Knowledge thrives on access to information. Recognizing this, the United Nations in 1945 adopted the Freedom of Information as a fundamental human right to which it is consecrated. Till date, 119 countries have enacted laws promoting access to information. However, the guarantee of the right to know goes beyond the passing of legislation to the establishment of capable implementing and enforcing institutions with clearly defined responsibilities to ensure that the laws are put into practice. This paper explores the institutional framework on the right to information in some jurisdictions-Nigeria, South Africa, Mexico and Hungary. It examines the implementing and enforcement models established in these jurisdictions. It finds that though each model has its advantages and disadvantages, the rate of success in the jurisdictions is largely influenced by local circumstances. It recommends that jurisdictions that are not making much progress in their enforcement efforts should reevaluate their design and make necessary adjustments, fully taking local circumstances and what works and what does not work for them into consideration; essentially the best practices.
\end{abstract}

\section{Keywords}

Access to Information, Democracy, Enforcement, Institutional Framework, Right to Information

\section{Introduction}

Knowledge thrives on access to information. Political, economic, social, environmental and holistic growth of the human society is based on effective communication and access to information. Information, which literally means to 
"give form to" or to shape one's thoughts (Sullins, 2019) is the currency that every citizen requires to participate in the life and governance of society. One of its essential elements is its ability to impact the receiver by adding or varying the receiver's thinking and action, no matter how little. The greater the access of the citizen to information, the greater the government's responsiveness to community needs (Singh, 2006). Indeed, information is the oxygen of democracy (RTI: A Guide to CSOs, 2006). The right to information (RTI) is, thus, critical in sustaining any democracy because an informed person translates into an empowered nation. The claim that Government withholds information for the public good is no longer acceptable as it has been observed that information is closely correlated with what constitutes human existence and that of everything around it. The implication of this is that information plays an important ontological role in the way the universe operates (Sullins, 2019).

The right to information not only guarantees accountability and transparency in governance, it also, to a large extent, helps to fight corruption. Where the right to information is impeded citizens will be unable to meaningfully participate in the process of governance; ultimately attempting to discredit the universally accepted definition of democracy as the "government of the people, by the people and for the people" (Lincoln, 1863). This is evident in the observation of the 1999 Joint Declaration on International Mechanism for Promoting Freedom of Expression that "Implicit in the freedom of expression is the public's right to open access to information and to know what governments are doing on their behalf, without which truth would languish and people's participation in government would remain fragmented."

The importance of the right to information is underscored by United Nations Resolution 59 (l) of 1945, which states that "Freedom of information is a fundamental human right and ... the touchstone of all the freedoms to which the UN is consecrated". The UN should indeed be consecrated to this right and its realization because as Koren (1997) observes, "the right to information should provide human beings with possibilities to taste the quality of authentic life." Notably, many governments worldwide have become more open by enacting laws that promote access to information. In 1776, Sweden became the first country to enact a law promoting access to information. This was followed by Finland, over a century and a half later, in 1919; the United States in 1966; and Norway in 1970. Till date, 119 countries-including South Africa in 2001, India in 2005 and Nigeria in 2011-had enacted the RTI laws. The latest entrants are Cyprus and Luxembourg (freedominfo.org 2017).

RTI, as a concept, is an offshoot of the Freedom of Opinion and Expression enshrined in the Universal Declaration of Human Rights (UDHR) (UN Doc. A/811, Arts 19, 1948). It is, therefore, a human right. On 17 November 2015, UNESCO adopted resolution (38 C/70) designating 28 September of each year as "International Day for the Universal Access to Information". The Right to Information is exercisable mainly in two ways. The first is the right to request and receive information, while the second is the obligation of public bodies to pub- 
lish information (Sadique, n.d.) Certain characteristics that mark the RTI are: the presumption of openness to the information held by public bodies; an enabling environment for exercising the right; and the fact that the right is not absolute and can be restricted, when appropriate. It has been established that though the passing of legislation is necessary to the realization of the right to information, it is not a sure guarantee of the right to know. There is need for the establishment of capable implementing and enforcing institutions with clearly defined responsibilities to ensure that the laws are put into practice (Torres, 2012).

This paper examines the institutional framework on the right to information in selected jurisdictions. After this introduction, it clarifies the right to information in Part II. Part III highlights the international and regional legal regime on the right to know whilst also noting the limitations on the right. Part IV examines the institutional framework on the right to know. It discusses some key models and how they operate in relevant jurisdictions with emphasis on Nigeria, South Africa, Mexico and Hungary. Part V concludes the paper.

\section{What Is Right to Information (RTI)?}

Right to information (RTI) and freedom of information (FOI) are used interchangeably. Right to Information is the freedom of people to have access to government's information. It is the ability of citizens and non-governmental organizations to enjoy reasonable free access to all files and documents pertaining to governmental operations, decisions, and performance (Torres, 2012). It is also the universal right to access information held by public bodies (Torres, 2012). According to Mendel (2004), freedom of information is most commonly understood primarily as a right to access information held by public bodies upon request. He notes further that a key element to the RTI is the obligation on public bodies to publish vital information, even in the absence of a request (Mendel, 2004).

RTI guarantees the right of an unhindered access to public information held by all federal government branches and agencies, and often includes those of private institutions in which any Federal, State or Local government has controlling interest and those private institutions performing public functions. It means having access to government data, information, records, files, documents in any form (Omotayo, 2015). For instance, Section 1 (1) of the Nigerian Freedom of Information Act 2011 provides that the right of any person to access or request written or unwritten information, is in the custody or possession of any public official, agency or institution howsoever described, is established. This guarantee is irrespective of the provisions of any other law. Section 31 of the Act defines public institution as any legislative, executive, judicial, administrative or advisory body of the Government, including boards, bureau, committees or commissions of the State, and any subsidiary body of those bodies including but not limited to committees and sub-committees which are supported in whole or in part by public fund or which expends public fund and private bodies providing 
public services, performing public functions or utilizing public funds. The section also defines information to include "all records, documents and information stored in whatever form, including written, electronic, visual images, sound, audio recording, etc." (Omotayo, 2015). The inference from these provisions is that it is virtually a no holds bar right of access to information.

Omotayo (2015) observes that in some jurisdictions, it may mean not only allowing access to government documents in whatever form they happen to exist, but also opening up the meetings of governments, their advisory bodies and client groups to public scrutiny the "open government" dimension. It may include access by individuals to files containing information about themselves and an assurance that the information is not being used for improper or unauthorized purposes. The utility of the RTI lies in the fact that, among others, it bridges the gap between the government and the people, making the former more responsive to the needs of the latter; and upholds the democratic ideology by promoting openness and transparency in administration, thus reducing corruption (Gopi, 2016). However, the realization of this goal has a direct bearing on the importance attached to the acquisition of information by both the government and the people. As James Madison aptly observes, "A popular government without popular information, or the means of acquiring it, is but a prologue to a farce or a tragedy or perhaps both. Knowledge will forever govern ignorance, and a people who mean to be their own governors, must arm themselves with the power knowledge gives" (Madison, 1822).

\section{International and Regional Legal Regime on the Right to Information}

The right to information was recognized as a fundamental right as early as 1946, during the first session of the United Nations General Assembly where Resolution 59 (1) was adopted (Omotayo, 2015). Indeed, the RTI has been recognized as being an essential part of the right to freedom of expression by international human rights tribunals such as the Inter-American and European Courts of Human Rights; and, along with the United Nations, other foremost international authorities such as the Organization of American States, Organization for Security and Cooperation in Europe and the African Commission (Transparency \& Accountability Initiative, 2011).

Article 19 of the UDHR states that everyone has the right to freedom of opinion and expression. This right includes freedom to hold opinions without interference and to seek, receive and impart information and ideas through any media and regardless of frontiers (UNGAR 217A (III)). The International Covenant on Civil and Political Rights (ICCPR) 1966, provides in similar terms as the UDHR that everyone shall have the right to hold opinions without interference. It further states that the right includes freedom to receive and impart information. (UNGAR 2200 A (XXI), Article 19) Article 13 (1) of the American Convention on Human Rights (ACHR) provides that everyone has the right to freedom of thought and expression. This right includes freedom to seek, receive, 
and impart information and ideas of all kinds, regardless of frontiers, either orally, in writing, in print, in the form of art, or through any other medium of one's choice (Article 13 ACHR).

The Inter American Commission on Human Rights adopted the Inter-American Declaration of Principles on Freedom of Expression in October 2000 and recognizes that every person has the right to access information about himself or herself or his/her assets expeditiously and not onerously, whether it be contained in databases or public or private registries; and, if necessary, to update it, correct it and/or amend it (Principle 3 IACHR). It further acknowledges that access to information held by the state is a fundamental right of every individual (Principle 3 IACHR). States have obligations to guarantee the full exercise of this right. The universality of the right of access to information and the United States commitment to it is evident in Obama's declaration.

We pledge to be more transparent at every level-because more information on government activity should be open, timely, and freely available to the people. We pledge to engage more of our citizens in decision-making-because it makes government more effective and responsive. We pledge to implement the highest standards of integrity-because those in power must serve the people, not themselves. And we pledge to increase access to technology-because in this digital century, access to information is a right that is universal (OGP Report, 2013).

The African Charter on Human and People's Rights, in Article 9 (1) (OAU Doc, 1982), states that "every individual shall have the right to receive information." The African Commission on Human and Peoples' Rights at its $32^{\text {nd }}$ Session in October 2002 adopted the Declaration of Principles on Freedom of Expression in Africa. Principle 4 states that "Public bodies hold information not for themselves but as custodians of the public good and everyone has a right to access this information, subject only to clearly defined rules established by law." The Committee of Ministers of the Council of Europe also adopted Recommendation No. R (81) 19 (2002) on Access to Information Held by Public Authorities. Principle III provides that "Member states should guarantee the right of everyone to have access, on request, to official document held by public authorities. This principle should apply without discrimination on any ground, including that of national origin." It is clear from the foregoing that RTI is a human right.

The Inter-American Court of Human Rights, in Claude Reyes and Others $V$ Chile (2006) held that "in respect of the facts of the present case, the Court considers that Article 13 of the Convention on Human rights in guaranteeing expressly the rights to "seek" and "receive" "information", protects the right of every person to request access to the information under the control of the State, with the exceptions recognized under the regime of restrictions in the Convention." Consequently, the said article encompasses the right of individuals to receive the said information and the positive obligation of the State to provide it in such form that the person can have access in order to know the information or 
receive a motivated answer when for a reason recognized by the Convention, the State may limit the access to it in the particular case. The information should be provided without the need to prove direct interest or personal involvement in order to obtain it, except in cases in which a legitimate restriction is applied (IACHR, Series C No 151, para 77).

In June 1999, ARTICLE 19, a non-governmental organization published "The Public's Right to Know: Principles on Freedom of Information Legislation", a set of principles setting out a number of standards in this area, drawn from international and comparative national practice. A primary goal of this document is to help promote progressive and effective freedom of information legislation, particularly in those countries currently developing such laws (Mendel, 2003). These guiding principles have been used by several countries making standard RTI laws. The principles are as follows - Principle 1 - Maximum Disclosure, Principle 2 - Obligation to Publish, Principle 3 - Promotion of Open Government, Principle 4 - Limited Scope of Exceptions, Principle 5 - Process to Facilitate Access, Principle 6 - Costs, Principle 7 - Open Meetings, Principle 8 - Disclosure Takes Precedence, and Principle 9 - Protection for Whistle-blowers.

\section{Limitations on the Right to Information}

Like other human rights, the right to information is not absolute and can be derogated from in certain instances. International instruments and legislation restrict RTI. The restrictions may be

1 ) in the interest of national security, territorial integrity or public order (Article 19 (3) ICCPR),

2) for the prevention of disorder or crime,

3) for the protection of health or morals,

4) for the protection of the reputation and rights of others (Article 19 (3) ICCPR),

5) for preventing the disclosure of information received in confidence (Loucaides, 1995), or

6) for maintaining the authority and impartiality of the judiciary.

The restrictions must, however, be provided for by law. They must pursue a legitimate aim and must be necessary to secure such legitimate aims as stated in article 19 (3) of the ICCPR (Mendel, 2003). For example, in Nigeria, Sections 11, 12,14 - 17 exempt the disclosure of information which could damage the conduct of international affairs and defence of Nigeria; information on administrative law enforcement proceedings and investigation; personal information; third party information such as trade secrets and commercial or financial information; information and records pertaining to professional privileges, journalism confidentiality, legal practitioner and health worker privileges. Even then, these exemptions can be overridden if the public interest consideration in their disclosure is higher than the injury disclosure would cause (Sections 11 (2), 12 (2), 14 (3), 15 (4), 19 (2) and 25 (1) (c)). The problem, however, is that "public interest" is not defined. Thus, the determination as to what exactly constitutes public in- 
terest and when it can be said to outweigh the harm disclosure might cause becomes uncertain.

This is a serious omission since public interest consideration constitutes a key element on which the effectiveness of much of the application of the Act depends. Admittedly, public interest is generally associated with the common well-being or general welfare of the people. Nevertheless, it is a vague concept that cannot be circumscribed (Vonk \& Tollenaar, 2008). It is thus a decision left to the discretion of relevant public officers or the court with no identified yardstick for its measurement. This constitutes a hindrance to the effective implementation of the Act, (Ogbuitepu, 2011) which should not be the case as the right to ATI is not a bonus right, but a basic right that is crucial to the overall constitutional pursuit for human dignity.

\section{Institutional Framework on the RTI}

International experience shows that to guarantee the RTI, nations must go beyond the passage of legislation. Neuman identifies four distinct phases in the establishment of an access to information regime. These are the passage of the law itself, implementation, use, and enforcement (Neuman, 2004, 2009). Institutional framework traverses implementation, use, and enforcement. As she explains

1) Implementation requires that procedures for dealing with information requests be put in place in individual government agencies.

2) Use entails individuals actually making use of the law to request government information. This requires that the public be aware of the law, be informed of how to use it, and not be overwhelmed by fear of reprisal.

3) Enforcement includes receiving appeals when the requester is denied all or partial access or there is a dispute over cost, investigating the complaints, and issuing a finding (Neuman, 2004, 2009).

Enforcement is carried out by oversight or dispute-resolution bodies, ideally free from political influence (Berliner, 2011). Significantly, the idea of enforcement has been merged with supervision or oversight such that a number of countries do not separate the responsibilities for enforcement from those of oversight. A single body is given the responsibility for both in such countries. Notwithstanding, the fact is that, in order to ensure full and continuing compliance with the law, there is need for statutorily mandated instruments dedicated to the promotion, monitoring and enforcement of the access to information regime (Torres, 2012).

Establishing clear responsibilities for an agency with a high degree of autonomy, free from political influence and with the capacity to set and implement related public policies is critical to practicalizing access to information laws (Torres, 2012). Autonomy implies that the body in charge of implementing and enforcing the RTI has sufficient independence to enable it maintain a distinctive identity (Wilson, 1989). This is necessary because of the nature of their respon- 
sibility - the regulation of provision and protection of information that are held by public agencies created with public funds. The regulation of RTI entails creating mechanisms that will control the political decisions on information disclosure; secure policy continuity and enhance governmental credibility (Gilardi, 2002); overcome political uncertainty (Moe, 1989); and protect citizens from administrative reticence to release information. Consequently, the RTI laws usually impose obligations on the state to take proactive measures to give effect to the right. Often times, this entails adequate institutional design such as a public body with powers and responsibilities to receive appeals and review disputed public body decisions on access to information requests. In addition to enforcement, this body is saddled with the responsibility to raise awareness by educating the public about their right to know and providing technical assistance to public bodies and the training of public officials in the field (Volodor, 2015).

The Organization of American States' Model Law on Access to Public Information emphasizes two matters related to institutional design: one, that it is imperative to have an agency dedicated to implementing the legislation; and two, that it is the exclusive authority of each country to determine which model will be best suited for it, depending on its specific political, economic, and social context and needs (Volodor, 2015). This explains the varied nature of the institutional enforcement models applicable in the countries that have adopted RTI laws. We will briefly examine some of these models citing examples of some of the countries in which they are applicable. The choice of the jurisdictions discussed under the models reflects not only the unique application of these models in some of the jurisdictions, such as Mexico and, especially, Hungary, but also the existence of the diversity of application within some of the models. Because implementation cannot frequently be strictly separated from enforcement, particularly since both roles are often performed by the same body, the discussion will, as much as necessary, encompass both. Reliance will be made on Neuman's insightful work on Enforcement Models: Content and Context, which generally categorizes them into three models (Neuman, 2009).

\section{a) Judicial Proceedings}

This model provides direct appeals to the judiciary when a request is refused under circumstances that are not satisfactory to the requester. The model is used in countries like Nigeria, South Africa, Bulgaria, Israel and the United States at the federal level. When a request for information is denied, the requester must appeal to the High Court or Federal High Court in Nigeria, (ss 7, $20 \& 32$, FOIA, 2011), the High Court in South Africa (ss 1 and 78, PAIA, 2000; Calland, 2009), an administrative court in Bulgaria (ss $40 \& 41$ j, APIA, 2000), or the Federal Court in the United States (s 552 (4) (B) FOI Act, 5 U.S.C). The major advantages of this model are that the courts have the power to order the release of information, if inappropriately denied (s 25 FoI Act 2011, Art 41 (1) APIA, s 82 PAIA, s 552 (4) (F) (i)); possess wide-ranging powers of investigation; have clearly established mechanisms for punishing agency noncompliance (Art 41, 
APIA), and may determine the procedural and substantive matters de novo (s 552 (4) B) i.e. the courts address the matter as if it is the first determination, even though they may give some deference to the agency that had given the first decision.

The disadvantages of the model, however, outweigh its benefits. Among them are the high cost of court proceedings, delay in trials and lack of confidence in the judicial system, which makes the option less attractive to information requesters. With respect to Nigeria, which has no specified single implementing authority; public institutions, being the chief implementing entities (ss 2, 9 and 13) under the oversight authority of the Attorney-General of the Federation (s 29 (1)-(8), recourse to the court is the only means of enforcement of the FoI Act. Incidentally, most people are litigation-averse and would rather suffer in silence or seek extra-legal means to solve their problem than use the courts. The snail pace of court proceedings, coupled with the level of poverty in the country, clearly does not encourage recourse to the court such that it can be expected that even when relevant information is not published or people are denied access to requested information, they may not avail themselves the opportunity of recourse to the court.

This impacts negatively on the effective implementation of the provisions of the Act in a country where public institutions do not have a culture of record keeping, even when the law mandates them to do so. In fact, there is a deliberate refusal to keep record, either due to lack of proper appreciation of the importance of record keeping or as an attempt to cover up shady activities, which only preserved records would concretely disclose. To heighten the problem, little effort is usually made to enforce the law(s) requiring record-keeping. The extent of the problem is documented in the Final Report of the 2012 fuel subsidy investigation panel, noting that contrary to statutory requirements and other guidelines under the Petroleum Support Fund (PSF) Scheme mandating agencies in the industry to keep reliable information data base, there seemed to be a deliberate understanding among the agencies not to do so. This lack of record keeping contributed in no small measure to the decadence and rots the Committee found in the administration of the PSF. This rot is evident also in the budget preparatory process by MDAs where adequate data is not made available to the National Assembly. The Committee had to resort to forensic analysis and examination of varied and external sources (including the Lloyds List Intelligence) to verify simple transactions (Resolution No. (HR.1/2012)).

How then does the Act expect information seeking individuals to be the ones to compel these institutions to keep such records through recourse to the court? The slow pace of court proceedings, even despite the provisions of the Act that such matters be heard and determined "summarily" (defined as "Short, without the usual formalities, immediate, done without delay" (Black's Law Dictionary, 1990) is manifest in the lamentation of the Executive Director of the Socio-economic Rights Action Project (SERAP) that SERAP had filed eight cases relating to Freedom of Information which were denied by various public institu- 
tions and officials that are still pending before the Court more than a year after the cases were filed. He attributes this delay to the failure of judges and defence counsel to appreciate the intention and spirit behind Section 21 of the FOI Act which envisages that such matters must be conducted with dispatch (Mumuni, 2014).

As can be seen from the foregoing, out of Neuman's identified four phases in establishing an access to information regime, enforcement constitutes the most problematic phase for Nigeria. The law, of course, has been passed, even though there are obvious gaps such as non-provision of sanction for non-compliance with critical provisions of the Act (s 3(f); Dunu \& Ugbo, 2014), and providing exemptions to access to information (ss 11 (2), 12 (2), 14 (3), 15 (4), 19 (2) and 25 (1) (c)), which are aivable on overriding public interest consideration; a vague concept which the Act fails to define (Udombana, 2016). Beyond the first phase, the next two phases: establishment of procedures for dealing with information requests; and public awareness and actual use of the law - are incrementally being realized (Adoke, 2013, Enwerem, 2014, Mumuni, 2014). Doubtlessly, though, there are challenges in these phases such as lack of sufficient training for heads of FOI designated units in public institutions (Enwerem, 2014). Another challenge is the practice of storing records in hard copies only, which slows down or affects the rate of compliance with the Act's provision in Section 2 (4) that information should be given in different forms, including electronically (Omonuwa, 2012). These and other such challenges need to be addressed for a more effective workability of the Act.

With respect to South Africa, Calland (2009) describes the court appeal system as using "a hammer to smash a corn". He acknowledges that the Promotion of Access to Information Act (PAIA) is excellent in most respects and is underpinned by a constitutional right. Unlike many developing countries elsewhere in Africa, or in Asia or Latin America, the South African court system is both functional and mainly honest, such that one can confidently say that the rule of law prevails in South Africa and anyone who takes a case to court stands a good chance of getting justice (Calland, 2009). Nevertheless, he notes that this does not necessarily imply that there is access to justice. This point is substantiated by the observation of Kader Asmal, Chair of the South African Ad Hoc Parliamentary Committee appointed to consider the future of Chapter 9 constitutional protection bodies that "The complex and potentially expensive appeals mechanism provided for in the legislation places further obstacles in the way of ordinary individuals wishing to access information ... it is significant that only a handful of cases reach the courts" (Calland, 2009). The Committee recommended, in consequence, that a dedicated information commissioner, with the mandate to receive appeals and make binding orders on access and disclosure, should be appointed within the South African Human Rights Commission (SAHRC). This recommendation flowed from doubts as to the capacity of the SAHRC to provide real teeth in implementing PAIA (Calland, 2009).

The PAIA is enforceable by the SAHRC and applies to both public and private 
institutions and all records irrespective of the time the records came into existence (s 3 PAIA). The SAHRC is mandated to compile and make available a guide on how to use the PAIA and submit reports to the National Assembly. Furthermore, it must develop and conduct educational programmes to advance the understanding of the public, in particular of disadvantaged communities, of the Act and of how to exercise the rights contemplated in the Act; encourage public and private bodies to participate in the development and conduct of the said educational programmes and to undertake such programmes themselves; promote timely and effective dissemination of accurate information by public bodies about their activities; and monitor the implementation of the Act, among other things (s 83 PAIA).

Critical to the associated downside of the judicial proceedings model is Neuman's observation that the cost, the delay, and the difficulty for citizens in accessing the courts have a chilling effect on the utilization of this enforcement mechanism. With all these obstacles, the deterrent effect that courts often play is minimized and may actually encourage a perverse incentive among some civil servants to ignore the law or arbitrarily deny requests, as they recognize that most persons will not be able to effectively question their decisions (Neuman, 2009). In addition to all these, is the litigation cost for the government provided for with the tax payers' money (Open Democracy Advice Centre, 2003). Further disadvantages of this model include the fact that in countries with continental judicial systems, it may be more difficult to achieve a common pattern of resolutions, and delimit judges' discretion (Rosenburg, 1991; Torres, 2011). Also, since courts lack the capacity to implement, their ability to achieve bureaucratic policy change generally depends on the cost - benefit analysis of agencies (Spriggs II, 1996). Finally, in systems with a persistent culture of secrecy, it may be difficult to overcome it through only the action of judges (Torres, 2011). It seems that, overall, this is an anti-productive model.

\section{b) Information Commission or Tribunal: Order Making Powers}

In this model, external appeals are first made to an ATI commissioner or specific appeals tribunal having the power to make rulings and binding orders before further recourse can be made to the court, if the need still arises. Generally, these bodies are established to reduce the workload of generalised courts and develop expertise and uniformity in the resolution of cases. The model, which is frequently seen as the best of the three models, is found in India, Scotland, Mexico, Ireland, among others (Hansen, Johnson, \& Unah, 1995).

In Mexico, for instance, the extant law is the Federal Transparency and Access to Public Government Information Act passed in June 2002. It is the most acclaimed law on ATI administration in the country and ranks as one of the most successful in terms of implementation and enforcement. Its unique features include the right to request information electronically (arts 9, 20 and 61) and the deemed approval of a request in the face of administrative silence (art 53). The Federal Institute for Access to Public Information (IFAI) serves as an independent enforcement body of the law. It is a body of the Federal Public Administra- 
tion (FPA) with operational, budgeting and decision making autonomy, in charge of promoting and disseminating the right to access public information, issuing resolution on denial of requests for access to information, and protecting personal data in possession of departments and agencies (art 33). Every public agency within the FPA appoints a Liaison Unit, which takes charge of managing requests, assisting petitioners and organizing the information (art 28). The agencies also create a Committee of Information, which is responsible for the general application of the legislation (art 29).

The Institute receives appeals following internal review decisions (art 37 II, 49 and 50), and makes its resolutions and decisions with full independence (art 34). If it upholds the agency's determination to deny release of information, or any other agency's decision, the requester has a right to judicial review (art 59). If the five-member board of the Institute finds in favour of the requester, it has the power to order the agency to act in accordance with its ruling (art 59). Interestingly, if the Institute overturns the agency's decision, the order is binding and final. In other words, the agency has no right of judicial review (Neuman, 2009; Torres, 2011). In addition to the above role, IFAI also regulates access to information and personal data; the training of public officers on access to information and personal data and their responsibilities in the implementation; and the promotion of legislation and transparency (Torres, 2011; arts 37 and 38).

The popularity of this model is connected to international standards on ATI laws and the rising pressure from coordinated civil society campaigns for countries to adopt the model in the belief that the commissioner's or tribunal's powers to make binding order will better enhance enforcement,. Neuman, however, cautions against the wholesale adoption of any model without first taking into consideration local circumstances and what works best for each jurisdiction (Neuman, 2009). She identifies the advantages of the model as follows

1) It is usually more accessible and affordable since legal representation, and court costs and other fees are, generally, not required,

2) In the best cases, it is extremely independent,

3) It allows the decision makers to become specialists in the area of access to information,

4) It serves as a deterrent to the government and can alleviate the need for further appeals to the courts since the commissioner or tribunal has the power to order agencies to act or apply sanctions,

5) Binding decisions are issued through a written ruling, which creates a body of precedent that can guide future internal agency and commissioner decisions and facilitate settlements in established jurisdictions (Neuman, 2009).

In essence, the model promotes the principles of independence, affordability, accessibility, timeliness, and specialisation. She equally notes that it is not in all cases that these benefits are attained, pointing out some of the disadvantages as-

1) Like judicial actions, such quasi-judicial proceedings, may become too formalistic and legalistic. For instance, in Jamaica, the appeals tribunal is in some ways more arduous than a judicial court, because of the necessity for pre- 
scribed submissions, and the requirement that appellants provide all the findings of fact and of law, grounds for appeal, witness lists, etc. in writing,

2) Decisions contain terminologies that may be difficult for requesters to understand,

3) The administration may be slower because more exhaustive investigations must be undertaken, due process requirements fulfilled, and lengthy judgments written and issued,

4) The probability of higher cost for the state as new institutions are established and staffed, and technical procedures like summons and notice, in-camera reviews, and hearings are applied to satisfy legal necessities,

5) Although the proceedings are said to be "binding," in the face of agency noncompliance, there is still need for recourse to judicial involvement and, in the most extreme cases, police engagement.

c) Information Commissioner or Ombudsman: Recommendation Power

This model uses an information commissioner or ombudsman but with more limited capacities for enforcement. It is operational at the federal level in Canada, Hungary, Sweden, Australia, Spain and New Zealand, among others. Here the commissioner or ombudsmen who usually have weaker powers of investigation is vested exclusively with the power to make recommendations to the relevant administrative agency or public functionary. Also, since they lack order-making powers they are inclined to emphasising negotiation and mediation. As indicated above, Hungary is one of the countries that practice this model.

With the fall of communism in 1989, the Hungarian Constitution was amended to reflect the new democratic order. This resulted in the addition of the right to information, among others, in the Constitution (Reuters, 1989; Neuman, 2009). Prior to this time, however, the foundation for the freedom of information Act had already been laid through the activities of the KSH group, the Hungarian Central Statistical Office, which collected and analysed western debates, publications, laws, and legal practice, including international documents and initiatives pertaining to the protection of personal data and freedom of information (Sekely, 2009). This resulted in the draft of two versions of a bill that combined the right to information and data protection, which became the framework for Hungary's combined Data Protection and Freedom of Information Act 1992. The remarkable thing about the Hungarian position was that it combined the traditional ombudsman role with the right-to-information enforcement under a joint protector to ensure that freedoms were not curtailed (Majtenyi, 2001 and 2002; Neuman, 2009). The ombudsman maintains the data protection register, provides opinions on data protection and information access-related draft legislation, as well as each category of official secret (Banisar, 2006).

The uniqueness of the system is manifest in several other ways such as the fact that although the ombudsman's recommendations were not binding, through their "simple declarations of law, valuing what is reasonable and just," they are sometimes considered more powerful than legal obligations (Majtenyi, 2001). Vested with wide powers for investigation, the ombudsman's office can enter 
agency premises. Unlike other similar bodies with recommendation power only, the ombudsman has the order-making power to mandate declassification of documents. The only recourse to this is either to concede or file a judicial appeal. All legislation that can affect the right to data protection and freedom of information must be reviewed by the ombudsman, an innovative and powerful tool in preserving the rights. Additionally, having been appointed by two-thirds of Parliament and serving in a high-ranking position, the ombudsman enjoys great legitimacy. If vested with any more powers, the office would have been akin to a judge rather than an ombudsman. Though the office sits within the parliamentary structure, it is not a part of the bureaucracy, thus offering it greater independence (Neuman, 2009).

There has been a remarkably high compliance with the ombudsman's recommendations. (Neuman, 2006) On the one hand, the benefits of the model include

1) Lack of formalism, which encourages accessibility for complainants,

2) Speed, since the investigations are generally limited to unsworn representations (Neuman, 2006)

3) The abridged powers may encourage less adversarial relations between the recommender and the implementer, with the ombudsmen relying more on resolution through persuasion and dialogue, potentially leading to greater compliance,

4) The independence of ombudsmen may be augmented by their status as officers of the legislature (Parliament) rather than as a quasi-independent part of the executive, which often is the case for information commissioners with order-making powers (Neuman, 2009).

On the other hand, despite the seeming success of the Hungarian system, the model suffers the following disadvantages, among others

1) Lack of adherence to the recommendations since the commissioner/ombudsman has no order making powers,

2) Over time, even those bodies vested with the more limited powers of investigation and recommendation may become increasingly formalistic, contentious, and slow,

3) A body of rulings may not be created that can guide future agency determinations on disclosure, although some jurisdictions like New Zealand may publish case notes that can be relied on by government agencies as decision making guide,

4) Emphasis is often placed on mediation and negotiated resolution, notwithstanding that one of the parties (requester or agency) might clearly be correct in its assertions,

The three models presented above clearly comply with the two matters related to institutional design indicated by the Organization of American States' Model Law on Access to Public Information, which are: one, that it is imperative to have an agency dedicated to implementing the legislation; and two, that it is the exclusive authority of each country to determine which model will be best suited for it, depending on its specific political, economic, and social context and needs. 
This accounts for the variation in the models, each of which has its rate of success and failure. The failure rate is, however, wider in some of the jurisdictions, specifically, Nigeria and South Africa, due, obviously, to the failure to sufficiently take the local circumstances in these countries into consideration before settling for such models.

\section{Conclusion}

This paper has examined the institutional framework on the right to information. It clarified the right to know, highlighted the international and regional legal regime on the right, and discussed some key models of institutional framework and how they operate in relevant jurisdictions such as Nigeria, South Africa, Mexico and Hungary. The emphasis on the promotion of the right to information is not aimed at imposing undue burden on public and, as the case may be, private institutions. The responsibilities imposed on such institutions by the various laws on the right to information constitute a vital part of the mechanism to ensure good governance and the positive transformation of the society. It is in this light that one appreciates Puddephatt's (2009) observation that traditionally secretive governments and bureaucracies have, at some points in time, embraced a commitment to openness partly because of broader social or political change, which has shifted power to new political leaders who are more open to persuasion, and partly because greater transparency is seen as a way to rebuild trust in the face of long standing growing distrust of politicians.

As seen from the discussion, various institutional frameworks have been designed in various jurisdictions. This is in line with the indication of the Organization of American States' Model Law on Access to Public Information that it is the exclusive authority of each country to determine the best design for its political system. Each of the frameworks that have been designed has its merits and demerits. There is no one size that fits all frameworks. Different considerations, obviously, underlined the choice for each country. However, the success rate of the choice in some jurisdictions is higher than that in some others, which may be an indication that the jurisdictions witnessing low performance may not have sufficiently taken into consideration its specific political, economic, and social contexts and needs in the formulation of its design. Nigeria and South Africa, for instance, have apparently not recorded much progress in the implementation and enforcement of their laws due to their chosen design, which makes recourse to the court the only enforcement option. This has left access to information largely unrealized. It is recommended that jurisdictions that are not making much progress in their enforcement efforts should reevaluate their design and make necessary adjustments, fully taking local circumstances and what works and what does not work for them into consideration.

\section{Conflicts of Interest}

The authors declare no conflicts of interest regarding the publication of this paper. 


\section{References}

(1990). Black's Law Dictionary, Centennial Edition (1891-1991). St. Paul, MN: West Publishing Co.

Adoke, B. (2013). Guidelines on the Implementation of the Freedom of Information Act 2011, Revised Edition. Abuja: Federal Ministry of Justice.

Banisar, D. (2006). Freedom of Information around the World. Privacy International.

Berliner, D. (2011). The Strength of Information Laws after Passage: The Role of Transnational Advocacy Bodies. 1st Global Conference on Transparency Research, Newark: Rutgers University

Calland, R. (2009). Illuminating the Politics and the Practice of Access to Information in South Africa. http://foip.saha.org.za/uploads/images/PW Chap1.pdf

Dunu, I., \& Ugbo, G. O. (2014). The Nigerian Journalists' Knowledge, Perception and Use of the Freedom of Information (FOI) Law in Journalism Practices. Journal of Media and Communication Studies, 1, 9.

Enwerem, P. C. (2014). The Right to Know and the Implementation of Freedom of Information Legislation: Case Study of Nigeria and South Africa (p. 56). M.A. Thesis, Budapest: Central European University.

Final Report of the House of Representatives Ad-Hoc Committee to Verify and Determine the Actual Subsidy Requirement and Monitor the Implementation of the Subsidy Regime in Nigeria. Resolution No. (HR.1/2012) 5. Laid on Wednesday, 18 April 2012.

Freedominfor.org (2017). Chronological and Alphabetical Lists of Countries with FOI Regime. http://www.freedominfo.org/?p=18223

Gilardi, F. (2002). Policy Credibility and Delegation to Independent Regulatory Agencies: A Comparative Empirical Analysis. Journal of European Public Policy, 9, 873-893. https://doi.org/10.1080/1350176022000046409

Gopi, M. (2016). Right to Information Act in India. Journal of Political Sciences \& Public Affairs, 4, Article ID: 1000207. https://doi.org/10.4172/2332-0761.1000207

Hansen, W. L., Johnson, R. J., \& Unah, I. (1995). Specialized Courts, Bureaucratic Agencies and the Politics of U.S. Trade Policy. American Journal of Political Science, 39, 529-577. https://doi.org/10.2307/2111643

Koren, M. (1997). The Right to Information: A Human Right of Children. IFLA Journal, 23, 57-59. https://www.ifla.org/files/assets/faife/lectures-papers/koren.pdf https://doi.org/10.1177/034003529702300111

Lincoln, A. (1863). The Gettysburg Address. http://www.abrahamlincolnonline.org/lincoln/speeches/gettysburg.htm

Loucaides (1995). Essays on the Developing Laws of Human Rights 24. London: Martinus Nijhoff Publishers.

Majtenyi, L. (2001). Freedom of Information, the Hungarian Model. Speech Delivered at the 4th International Conference on Information Society, 21 October 2001, Vilnius Lithuania, Organised by the Brandenburg State Commissioner for Data Protection and Access to Information.

Majtenyi, L. (2002). Ensuring Data Protection in East-Central Europe. Social Research, 69, 151-176.

Mendel, T. (2003). Freedom of Information as an Internationally Protected Human Rights. Comparative Media Law Journal, 1, 39-70.

Mendel, T. (2004). Freedom of Information: A Comparative Legal Survey. Paris: UNESCO. http://unesdoc.unesco.org/images/0015/001584/158450e.pdf

Moe, T. (1989). The Politics of Bureaucratic Structure. In J. Chubb, \& P. Peterson (Eds.), 
Can the Government Govern (pp. 267-329). Washington DC: Brookings Institution Press.

Mumuni, A. (2014). Litigation Issues in Freedom of Information Act 2011. In 34th Advanced Course in Practice and Procedure, Module II (pp. 5-6). Lagos: The Nigerian Institute of Advanced Legal Studies.

Neuman, L. (2004). Access to Information Laws: Pieces of the Puzzle in the Promotion of Democracy through Access to Information Bolivia. Atlanta, GA: GA Carter Center.

Neuman, L. (2006). Mechanisms for Monitoring and Enforcing the Right to Information around the World. In Access to Information: Building a Culture of Transparency (p. 54). Atlanta, GA: Carter Center.

Neuman, L. (2009). Enforcement Models: Content and Context. Access to Information Working Paper Series.

http://siteresources.worldbank.org/EXTGOVACC/Resources/LNEumanATI.pdf

OAU Doc (1982). CAB/LEG/67/3 Rev. 5, 21 I.L.M. 58.

Ogbuitepu, F. (2011). An Analysis on the Practicality of the Nigerian Freedom of Information Act 2011. Nigerian National Human Rights Commission Journal, 1, 9.

Omonuwa, E. O. (2012). Some of the Challenges of the Implementation of the Current Guidelines on Freedom of Information Act 2011 (FOIA). Abuja: Federal Ministry of Justice and United Nations Development Programme's Consultative Forum on the Revised Guidelines on the Implementation of the Freedom of Information Act, Olusegun Obasanjo Auditorium, Federal Ministry of Justice, Complex.

Omotayo, F. O. (2015). The Nigerian Freedom of Information Law: Progress, Implementation, Challenges and Prospects. Library Philosophy and Practice (e-Journal), 1219.

Open Democracy Advice Centre (2003). The Promotion of Access to Information Act: Commissioner Research on the Feasibility of the Establishment of an Information Commissioner's Office, Cape Town.

Puddephatt, A. (2009). Exploring the Role of Civil Society in the Formulation and Adoption of Freedom of Information Laws, the Cases of Bulgaria, India, Mexico, South Africa and the United Kingdom. World Bank Institute, Access to Information Working Paper Series 47992.

http://documents.worldbank.org/curated/en/302751468044082294/pdf/479920WBWP 0Acc10Box338877B01PUBLIC1.pdf

Reuters (1989). Hungary Purges Stalinism from Its Constitution. New York Times.

Rosenburg, G. (1991). The Hollow Hope: Can Courts Bring about Social Change (2nd ed.). Chicago, IL: University of Chicago Press.

Sadique, M. (n.d.). Right To Information: A Fundamental Right. http://rti.img.kerala.gov.in/RTI/elearn/RTI-fundmental-HR-sadique.pdf

Sekely, I. (2009). Hungary. In J. B. Rule, \& G. Greenleaf (Eds.), Global Privacy Protection: The First Generation (p. 178). Cheltenham: Edward Elgar Publishing.

Singh, Y. P. (2006). Indian Village: 2020 (Vols. 1 \& 2, p. 43). New Delhi: Concept Publishing Co Ltd.

Spriggs, J. F. II (1996). The Supreme Court and Federal Administrative Agencies: A Resource-Based Theory and Analysis of Judicial Impact. American Journal of Political Science, 40, 1122-1151. https://doi.org/10.2307/2111745

Sullins, J. (2019). Information Technology and Morals. In E. N. Zalta (Ed.), The Stanford Encyclopedia of Philosophy (Summer 2019 Edition).

https://plato.stanford.edu/archives/sum2019/entries/it-moral-values

The Open Government Partnership OGP (2013). Government Self-Assessment Report 
for the United States of America.

The Right to Information RTI (2006). A Guide to Civil Society Organizations. NIA, Capacity Building for Access to Information. A GoI-UNDP Initiative foip.saha.org.za.

Torres, N. (2011). Institutional Design for an Effective Access to Information: New Developments in Latin America. In First Global Conference on Transparency Research.

Torres, N. (2012). Access to Information in Columbia: 124 Years Later. http://www.freedominfo.org/2012/07/access-to-information-in-colombia-124-years-lat $\underline{\text { er }}$

Transparency \& Accountability Initiative (2011). Opening Government: A Guide to Best Practice in Transparency, Accountability and Civic Engagement across the Public Sector. http://freedominfo.org/documents/OGP2011pelimreportFinal\%20Document.pdf

Udombana, N. J. (2016). Quality of Legislation: A Case Study of Nigeria's Freedom of Information Act 2011. NIALS International Journal of Legislative Drafting, 2, 18.

United Nations General Assembly (UNGA) (1948). UN Doc. A/811, Arts 19.

Voloder, N. (2015). Right to Information in BiH: Towards Effective Institutional Design. Analitika. Centre for Social Research, Policy Brief 19.

http://www.analitika.ba/publications/right-access-information-bih-towards-effective-i nstitutional-design

Vonk, G. J., \& Tollenaar, A. (2008). The Public Interest and the Welfare State: A Legal Approach. Working Paper Annual Legal Research Network Conference, Groningen. https://doi.org/10.2139/ssrn.1269372

Wilson, J. (1989). Bureaucracy: What Government Agencies Do and Why They Do It 182. New York: Basic Books. 